\title{
WIESŁAW ŚMIGIEL \\ Synod diecezjalny jako wyraz kolegialności Kościoła i szansa na ożywienie duszpasterstwa
}

Synod diecezjalny jest ważnym wydarzeniem w życiu Kościoła lokalnego i może mieć pozytywny wpływ na duszpasterstwo. Znacznie zyskał na znaczeniu w związku z uwydatnieniem w nauczaniu Kościoła roli diecezji, w której jest obecny i działa Kościół Chrystusowy (DB 11; EI 171). Diecezja nie jest tylko okręgiem administracyjnym i częścią Kościoła powszechnego, ale jest konkretnym jego uobecnieniem i jako część przedstawia całość ${ }^{1}$. W tak rozumianą diecezję wpisuje się synod diecezjalny jako jedna $\mathrm{z}$ form docenienia autonomii diecezji i realizacji zasady kolegialności (KK 22-23).

Już sama etymologia terminu synod (od gr. synodeuein - czyli odbywać razem drogę) sugeruje wspólnotowy i duszpasterski wymiar tej instytucji ${ }^{2}$. Najogólniej synod definiuje się jako zebranie wybranych kapłanów, przedstawicieli życia konsekrowanego oraz wiernych świeckich, którzy dla dobra całej wspólnoty diecezjalnej świadczą pomoc biskupowi diecezjalnemu, zgodnie z przepisami prawa (KPK kan. 460).

W historii idea synodu i jego główne zadania były niezmienne, ale modyfikacji ulegały jego przebieg, kształt i znaczenie. Sama instytucja synodów, mimo

Wiesław Ś M I G I E L, ks. dr hab., adiunkt w Katedrze Teologii Pastoralnej Ogólnej KUL, Lublin, e-mail: smigiel@kul.lublin.pl

${ }^{1}$ R. Ka mińs ki: Działalność zbawcza Kościoła $w$ teorii $i$ praktyce pastoralnej. Lublin 2007 s. 111.

${ }^{2}$ W. Gó r a 1 s k i: Synod diecezjalny. W: Leksykon teologii pastoralnej. Red. R. K a m i ń ski, W. Pr z y g od a, M. Fi ałk ow ski. Lublin 2006 s. 826. 
różnych kryzysów, trwa od Soboru Jerozolimskiego do czasów współczesnych ${ }^{3}$. W opinii niektórych teologów i kanonistów synod jest częścią tradycji normatywnej, stąd nie można go zmarginalizować w życiu diecezji, bez poważnych konsekwencji teologicznych ${ }^{4}$. Współcześnie wyraźnie widać przesunięcie akcentu z kanonicznego na duszpasterski charakter synodu. Nie jest on już tylko sposobnością do wypracowania norm prawnych, choć ten aspekt nie może zostać zlekceważony lub pominięty, ale jest również okazją do aktywizacji pastoralnej wszystkich stanów i środowisk w diecezji.

Niestety w Polsce, podobnie jak i w innych krajach europejskich, po dwóch okresach wzmożonej aktywności synodalnej (po Soborze Watykańskim II oraz po promulgowaniu Kodeksu Prawa Kanonicznego w 1983 r.), nastapił stopniowy zastój tej instytucji. Poza tym nawet II Polski Synod Plenarny (1991-1999) pozostaje w jakimś zakresie niedoceniony, gdyż współcześnie rzadko pojawią się odwołania do jego dokumentów końcowych ${ }^{5}$.

\section{Zarys historii instytucji synodu diecezjalnego}

Po raz pierwszy synody diecezjalne pojawiły się w III-IV w. na Wschodzie i VI w. na Zachodzie. Ich powstanie było głównie związane $\mathrm{z}$ tworzenie nowych ośrodków duszpasterskich w terenie, które z czasem zamieniły się w diecezje i parafie w naszym rozumieniu ${ }^{6}$. Historycy twierdzą, że pierwszym synodem, który wydał ustawy, a jego akta zachowały się, był synod w Auxerre (między 561 a $605)^{7}$. Natomiast pierwszą ustawę powszechną o synodzie diecezjalnym wydał Sobór Laterański IV (1215), została ona włączona do „Dekretałów” Grzegorza IX (1234). Ustawa podkreślała, że synod w diecezji powinien odbywać się każdego roku, aby w ten sposób zagwarantować aplikację norm synodów prowincjonalnych ${ }^{8}$.

\footnotetext{
${ }^{3}$ Instytucja synodów przez długi czas nie była w Kościele odróżniania od soborów powszechnych (ekumenicznych).

4 J. Perszon: Ecclesia semper reformanda? Kolegialność Kościoła w posoborowej eklezjologii amerykańskiej. Toruń 2009 s. 383.

${ }^{5}$ Zob. II Polski Synod Plenarny (1991-1999). Pallottinum. Poznań. 2001.

${ }^{6}$ Początkowo synody oznaczały zebranie biskupów sąsiadujących ze sobą, bądź należących do jednej prowincji. Źródła historyczne poświadczają takie zebrania już w połowie II w. Do czasów Grze g or z a W i e 1 k i e g o potwierdzono ponad 400 synodów. Zajmowały się one problemami doktrynalnymi i pastoralnymi. Jednak od czasów C y p r i a n a z Kartaginy podstawowym zadaniem synodów było osiaggnięcie konsensusu w wierze i praktyce pastoralnej, co uznawano za działanie Ducha Świętego.

${ }^{7}$ Brało w nim udział 7 opatów, 34 prezbiterów i 3 diakonów z diecezji Auxerre. Ogłoszono tam 45 kanonów.

${ }^{8}$ W. G ó r a l s k i: Synod diecezjalny, dz. cyt., s. 826.
} 
Zasadniczo w średniowieczu synody diecezjalne były zwoływane raz lub nawet dwa razy w roku i trwały od jednego do trzech dni. Uczestniczyli w nich wszyscy duszpasterze lub ich delegaci. Za absencję na synodzie stosowano kary. Niektórzy, jak np. cystersi i mendykanci mieli przywilej nieobecności na synodzie. Sporadycznie na synodzie pojawiali się świeccy, głównie wpływowi i zamożni dygnitarze. Jednakże nie mieli oni prawa głosu, a w większości przypadków traktowano ich instrumentalnie, chodziło głównie o osiagnięcie konkretnych korzyści lub wyrażenie wdzięczności za już okazaną pomoc ${ }^{9}$.

Natomiast Sobór Trydencki wskazał na synod diecezjalny jako na podstawowe narzędzie urzeczywistniania soborowej reformy i odnowy na poziomie lokalnym. Ze zrozumiałych względów szczególnie często organizowano synody we wczesnym okresie wprowadzania w życie postanowień Soboru Trydenckiego. W późniejszym czasie uchylono normę o corocznym odbywaniu synodu, a o częstotliwości odbywania tych zgromadzeń decydowały wewnętrzne potrzeby diecezji. Poczynając od połowy XVIII w. rola synodu zaczęła stopniowo maleć, aż prawie zupełnie stracił on na znaczeniu ${ }^{10}$.

Synody diecezjalne powróciły wraz z promulgowaniem w 1917 r. Kodeksu Prawa Kanonicznego, który polecił zwoływanie takiego synodu przynajmniej raz na 10 lat. Poza tym postanowienia zawarte w Kodeksie wymagały kodyfikowania prawa partykularnego w poszczególnych diecezjach. Jednak synody pokodeksowe również dość szybko wyczerpały swoje możliwości. Tym bardziej, że kontakt biskupa diecezjalnego z duchowieństwem stawał się coraz łatwiejszy, a sprawy omawiane na synodzie mogły stać się przedmiotem zainteresowania konferencji pastoralnych duchowieństwa ${ }^{11}$.

\section{Synod diecezjalny dzisiaj}

Zmierzch tradycyjnego modelu synodu diecezjalnego zwiastował Sobór Watykański II, rozpoczynając nową epokę w dziejach tej instytucji ${ }^{12}$. Jednak trzeba pamiętać, że status teologiczny i prawny synodów jest ciagle dyskutowany ${ }^{13}$. Posoborowe próby większej demokratyzacji synodów diecezjalnych nie zawsze

\footnotetext{
${ }^{9}$ W. W ó j c i k: Synod diecezjalny w Nowym Kodeksie Prawa Kanonicznego. „Prawo Kanoniczne" R. 29: 1986 nr 1-2 s. 99.

${ }^{10}$ W. G ó r a 1 s k i, dz. cyt., s. 826.

${ }^{11}$ W. W ó j c i k, dz. cyt., s. 109-110.

${ }^{12}$ Ojcowie Soboru Watykańskiego II wyrazili życzenie, aby synod odżył z nową moca, by tym lepiej $i$ skuteczniej można się było przyczynić do wzrostu wiary $i$ zachowania dyscypliny $w$ różnych Kościołach, zależnie od okoliczności czasu (DB 36).

${ }^{13}$ Zob. E. S z t a f r o w s k i: Synod diecezjalny $w$ doktrynie soborowej i jej wyraz w posoborowych synodach polskich. „Prawo Kanoniczne”. R. 30: 1987 nr 1-2 s. 61-75.
} 
kończyły się sukcesem, podobnie jak chybione okazały się postulaty przekształcenia synodów w ciała w jakimś zakresie współrządzące Kościołem ${ }^{14}$. Trwająca dyskusja i nierozwiązane problemy nie zmienią faktu, że współcześnie synod diecezjalny zyskał na znaczeniu głównie ze względu na zaangażowanie wiernych świeckich i nastawienie pastoralne ${ }^{15}$.

Po 1965 r. w wielu krajach, poczynając od Holandii, zainicjowano synody o charakterze duszpasterskim, nawiązujące w swoich uchwałach nie tyle do norm prawa powszechnego, ile raczej do nauki i wskazań Soboru. Aspekt czysto normatywny, dominujący w dawnych statutach, został zredukowany, tym bardziej, że obowiązujący wówczas kodeks z 1917 r. w wielu sytuacjach duszpasterskich był anachroniczny ${ }^{16}$.

Charakterystyczny dla nowego typu synodu stawał się też coraz szerszy udział w obradach synodalnych wiernych świeckich. Duszpasterska orientacja synodu zaczęła się coraz bardziej wyrażać w aktywizowaniu całej wspólnoty kościelnej oraz w poszukiwaniu skutecznych dróg ewangelizacji, co wiązało się nie tylko z treścią uchwał końcowych, lecz również z odmienną niż dotąd formą ich przygotowania, sposobem oddziaływania na opinię publiczną oraz czasem trwania synodu. Synod rozciagnął swoje działanie na pracę zespołów synodalnych, nawet na poziomie parafialnym, co jednocześnie wpłynęło na wydłużenie czasu trwania synodu, nawet do kilku lat. W ten sposób synod diecezjalny zaczął stawać się znaczącym narzędziem pogłębiania wiary wspólnoty diecezjalnej i okazją do ożywienia duszpasterstwa ${ }^{17}$. Diecezja przeżywająca synod stała się szkołą komunii, uwrażliwiając wiernych na to, że są podmiotem duszpasterstwa.

Promulgowanie nowego Kodeksu Prawa Kanonicznego w 1983 r. sprawiło, że odnowione w duchu Soboru Watykańskiego II prawo powszechne, szeroko uwzględniające nowe potrzeby duszpasterskie, nie mogło pozostawać bez wpływu na dalszy bieg aktywności synodalnej w Kościołach partykularnych. Zaczęła się ona wyrażać w coraz powszechniejszym nawiązywaniu w uchwałach końcowych synodów do norm kodyfikacji nowego Kodeksu, co bynajmniej nie pozbawiło tych zgromadzeń charakteru duszpasterskiego. Nowe regulacje prawne Kodeksu stały się czynnikiem pomagającym w odnowie całokształtu dziedzin życia diecezjalnego, m.in. struktur duszpasterskich ${ }^{18}$.

\footnotetext{
${ }^{14}$ J. P e r s z o n, dz. cyt., s. 383.

${ }^{15}$ W. W ó j c i k, dz. cyt., s. 117.

${ }^{16}$ W. G ó r a 1 s k i: Synod diecezjalny, dz. cyt., s. 826.

${ }^{17}$ Tamże, s. 826-827.

${ }^{18}$ Tamże, s. 827.
} 
Kodeks Prawa Kanonicznego z 1983 r. ukształtował strukturę synodu diecezjalnego, czyniąc z tej instytucji formę współpracy biskupa diecezjalnego z prezbiterami, diakonami oraz pozostałymi kategoriami wiernych diecezji (KPK kan. 460-468) $)^{19}$. Zwołanie synodu całkowicie uzależnił od decyzji biskupa diecezjalnego, ilekroć jego zdaniem i po wysłuchaniu rady kapłańskiej, przemawiają za tym okoliczności. Kodeks stwierdził również, że biskup diecezjalny jest przewodniczącym synodu i jako jedyny ustawodawca na synodzie, ponieważ wszyscy inni uczestnicy mają tylko głos doradczy, podpisuje deklaracje i dekrety synodalne, promulgując je własnym autorytetem. Do biskupa diecezjalnego należy także przekazywanie do wiadomości treści tychże deklaracji i dekretów metropolicie i lokalnej konferencji episkopatu ${ }^{20}$.

Wśród uczestników synodu wyróżnia się pochodzących z urzędu, czyli biskup koadiutor, biskupi pomocniczy, wikariusze generalni, wikariusze biskupi, wikariusz sądowy, członkowie kapituły katedralnej, członkowie rady kapłańskiej, rektor wyższego seminarium duchownego oraz dziekani. Drugą grupę stanowią uczestnicy z wyboru - wśród nich są wierni świeccy oraz członkowie instytutów życia konsekrowanego wybrani przez radę duszpasterską w liczbie określonej przez biskupa diecezjalnego, kapłani wybrani w poszczególnych dekanatach, przełożeni zakonni, liderzy stowarzyszeń życia apostolskiego, które posiadają dom w diecezji, wybrani w liczbie określonej przez biskupa diecezjalnego. Trzecią grupę stanowią uczestnicy $\mathrm{z}$ nominacji biskupa diecezjalnego, którzy mogą rekrutować się spośród duchownych, jak i wiernych świeckich oraz członków instytutów życia konsekrowanego. Ponadto, biskup diecezjalny może powołać na synod - w charakterze obserwatorów - niektórych wyznawców Kościołów lub wspólnot kościelnych, które nie pozostają w pełnej wspólnocie z Kościołem katolickim ${ }^{21}$.

Tematy obrad synodalnych powinny być poddane swobodnemu omówieniu przez członków synodu podczas sesji synodalnych. Poza tym biskup diecezjalny ma dużą swobodę w sposobie przygotowania obrad synodalnych i samym przebiegu synodu. W kwestiach tych obowiązują ogólne wskazania instrukcji duszpasterskiej Ecclesiae imago z 1973 r. (nr 164-165). Według tego dokumentu przewiduje się powołanie komisji przygotowawczych, złożonych z duchownych, świeckich oraz członków instytutów życia konsekrowanego i stowarzyszeń życia

${ }^{19}$ Zob. L. J. J e n n i n g s: A renewed Understanding of the Diocesan Synod. „Studia Canonica”. T. 20: 1986 s. 319-354.

${ }^{20}$ W. G ó r a 1 s k i: Synod diecezjalny, dz. cyt., s. 827.

${ }^{21}$ Sobór Watykański II dostrzegł i dowartościował wiernych świeckich w Kościele, jednak nie mogli oni uczestniczyć w synodach bez pozwolenia Stolicy Apostolskiej. Dopiero Kodeks Prawa Kanonicznego z 1983 r. wprowadził taką możliwość, czyniąc z synodu forum dialogu biskupa diecezjalnego z przedstawicielami różnych stanów w diecezji. 
apostolskiego. Zadaniem tych komisji jest przestudiowania zagadnień, które mają być przedmiotem debaty synodalnej i dla przygotowania projektów dokumentów, które po zaaprobowaniu przez biskupa diecezjalnego będą dyskutowane podczas sesji synodalnych. W praktyce synodalnej spotyka się różnorodne formy aplikacji wskazań instrukcji duszpasterskiej Ecclesiae imago - w zależności od decyzji biskupa diecezjalnego ${ }^{22}$.

Gdy chodzi o profil uchwał końcowych synodu diecezjalnego to instrukcja De Synodis dioecesanis agendis z 1997 r. zwraca uwagę na potrzebę stanowienia na synodzie norm prawnych, które jednak nie wyczerpują zakresu możliwości synodu $^{23}$. Synod kończy się promulgowaniem statutów, które najczęściej dotyczą realizacji w diecezji funkcji nauczycielskiej, liturgicznej i pasterskiej. Ze względów praktycznych statutach może znajdować się także dokumentacja synodu (powołanie, skład komisji, przebieg prac itp.) oraz aneksy, zawierające wzory różnych pism wykorzystywanych w duszpasterstwie.

\section{Duszpasterski wymiar synodu diecezjalnego}

Analizując działanie i owocność różnych synodów można dojść do wniosku, że współcześnie kształtują się trzy formuły odbywania synodów: kanoniczna, konsultacyjna oraz wspólnotowa. Formuła kanoniczna polega na dokładnej aplikacji norm Kodeksu Prawa Kanonicznego z 1983 r. Celem synodu, w takiej konwencji, jest wypracowanie zwięzłych statutów, które będą regulować działalność pastoralną. W praktyce jeden zespół redakcyjny lub kilka komisji tematycznych, złożonych głównie $\mathrm{z}$ duchownych, przygotowuje projekt statutów. Jeśli następuje etap konsultacyjny, to przeważnie niewiele on wnosi ${ }^{24}$. Ta formuła była potrzebna w pierwszych latach po promulgowaniu nowego Kodeksu Prawa Kanonicznego.

W ramach formuły konsultacyjnej synod jest rozumiany jako sposobność do pogłębienia świadomości eklezjalnej oraz ewangelizacji. Dlatego też punkt ciężkości spoczywa na fazie konsultacji, która w praktyce polega na powoływaniu licznych grup synodalnych. Dzięki nim istnieje możliwość dotarcia do różnych środowisk, poznania prawdziwych problemów oraz sformułowania konkretnych wniosków i postulatów ${ }^{25}$.

\footnotetext{
${ }^{22}$ W. G ó r a 1 s k i: Synod diecezjalny, dz. cyt., s. 827.

${ }^{23}$ Tamże, s. 828.

${ }^{24}$ W. Ś m i g i e l: Uczestnictwo wiernych świeckich w budowaniu Kościoła-Wspólnoty. Studium teologicznopastoralne w świetle nauczania Kościoła (1961-2009). Lublin 2010 s. 83.

${ }^{25}$ Tamże.
} 
Formuła wspólnotowa natomiast dąży do przebudzenia wszystkich środowisk wiernych i ożywienia Kościoła. Kładzie się tutaj nacisk na fazę przygotowawcza, która polega na spotkaniu poszczególnych zrzeszeń laikatu, reprezentantów wszystkich stanów i grup społecznych. Opracowywanie dokumentów synodalnych $w$ takiej formule na znaczenie drugoplanowe ${ }^{26}$. Głównym zadaniem synodu staje się wyjście rozmaitych wspólnot z izolacji, pokonanie antagonizmów i przeżycie mocy Ducha Świętego przez tych, którzy utracili odwagę bycia Kościotem $^{27}$.

Formuła druga i trzecia mają największe nachylenie duszpasterskie. Poza tym takie rozumienie synodu lepiej realizuje postulaty rzeczywistej odnowy Kościoła, włączenia świeckich w działalność synodów oraz wykorzystania możliwości pastoralnych tej instytucji i właściwego odczytania jej semantyki teologicznej. W takim ujęciu synod to przede wszystkim święto Kościoła $w$ drodze, a nie tylko wyraz kolegialności ${ }^{28}$.

Statuty synodalne i konkretne postanowienia prawne nie są najważniejszym celem synodu, ale samo przygotowanie i trwanie synodu ma szczególne znaczenie. W trakcie prac poszczególnych komisji synodalnych, może dojść do spotkania i wymiany doświadczeń przez różne środowiska w diecezji. Jednak synodu o wymiarze wspólnotowym i duszpasterskim nie należy traktować jako przeciwstawienie dla synodu kanonicznego. Problem leży tylko w przesunięciu akcentu na duszpasterstwo, a nie całkowitej rezygnacji z normatywnego wymiaru synodu.

W związku z synodem warto również pomyśleć o duszpasterstwie synodalnym $^{29}$. U podstaw takiego duszpasterstwa leżą wysiłki zmierzające do pogłębienia wiary oraz zachęta do świadectwa w życiu codziennym, tak w wymiarze jednostkowym, jak i wspólnotowym. Synod jako doniosłe wydarzenie eklezjalne powinien mieć odzwierciedlenie w przepowiadaniu słowa, liturgii i diakonii. Chodzi tutaj o homilie, kazania i katechezy związane z tematami podejmowanymi na synodzie; chodzi również o nabożeństwa w intencji synodu, jak również o diakonię, która już w trakcie trwania synodu będzie przepojona jego wspólnotowym duchem i troską o potrzebujących. W takim ujęciu synod staje się wyzwaniem dla biskupa diecezjalnego, duszpasterzy i wiernych świeckich. Najpełniejszy wyraz synod diecezjalny znajduje w pełnym zaangażowaniu wszystkich stanów w diecezji.

${ }^{26}$ H. S e w e r y n i a k: Święty Kościót powszedni. Warszawa 1996 s. 229-230.

${ }^{27}$ Tamże, s. 230-231.

${ }^{28}$ Tamże, s. 233.

${ }^{29}$ Por. E. S z t a f r o w s k i: Synod diecezjalny $w$ doktrynie soborowej i jej wyraz $w$ posoborowych synodach polskich, dz. cyt., s. 64. 
Synod jest też okazją do pogłębienia wiedzy i eklezjalnej świadomości diecezji. Dlatego na spotkania synodalne można zapraszać ekspertów, którzy pogłębią intelektualnie poszczególne zagadnienia.

$\mathrm{Na}$ wszystkich etapach pracy synodu niezwykle ważna jest komunikacja, aby synod nie był tylko wydarzeniem dla elit diecezjalnych. Na tę komunikację składają się listy, odezwy, wystąpienia biskupa, jak również aktywność informacyjna wszystkich zaangażowanych w synod. W komunikacji synodalnej nie bez znaczenia jest też udział katolickich środków społecznego przekazu, które powinny zaangażować się $\mathrm{w}$ aktywizację diecezji.

\section{Wybrane schematy pomocne w organizacji synodu diecezjalnego}

Cel duszpasterstwa został wyznaczony przez Jezusa Chrystusa i pozostaje niezmienny od powstania Kościoła. Natomiast zmieniają się uwarunkowania historyczne i społeczno-kulturowe, co nieustannie zmusza do refleksji nad aktualnym kształtem duszpasterstwa. Synod diecezjalny jest właśnie jednym ze sposobów poszukiwania działalności zbawczej, która jest adekwatna do wyzwań współczesności.

Nie ma jednego sprecyzowanego schematu synodu diecezjalnego, gdyż jest on uzależniony od wielu czynników m.in. od przyjętej koncepcji synodu, celów i uwarunkowań. Każda diecezja musi w pewnym sensie nastawić się na szukanie własnych środków, które pozwolą najlepiej zrealizować cele duszpasterskie ${ }^{30}$. Jednak można wskazać na pewne ogólne schematy postępowania, które mogą znaleźć zastosowanie w organizacji synodu.

Jednym z takich schematów, który po pewnych modyfikacjach może okazać się pomocny jest paradygmat wypracowany przez kard. J. Cardijna (1882$1967)^{31}$. Schemat ten znalazł szerokie zastosowanie jako metoda konfrontacji życia $\mathrm{z}$ Ewangelią $\mathrm{w}$ różnych zrzeszeniach religijnych m.in. w francuskim związku Chrześcijańskiej Młodzieży Robotniczej (Jeunesse Ouvrière Chrétien e) oraz w Akcji Katolickiej. Na gruncie polskim odwołał się do niego ks. Franciszek Blachnicki wprowadzając ewangeliczną rewizję życia do formacji Ruchu „Światło-Życie” ${ }^{32}$. Jego istotę wyraża triada: widzieć, ocenić, działać ${ }^{33}$. Taki

\footnotetext{
${ }^{30}$ Tamże, s. 64.

${ }^{31}$ Zob. W. P r z y g o d a: Paradygmaty metodologiczne we wspótczesnej teologii pastoralnej. „Teologia Praktyczna”. T. 10: 2009 s. 33-36.

${ }^{32} \mathrm{R}$. Ka miń s ki: Biblia $w$ życiu parafii $i$ matych wspólnot religijnych. W: Biblia $w$ nauczaniu chrześcijańskim. Red. J. K u d a s i e w i c z. Lublin 1991 s. 157-158.
} 
sposób postępowania badawczego poparł papież Jan XXIII w encyklice Mater et Magistra (nr 236) i z powodzeniem stosował w całym swoim nauczaniu społecznym. Paradygmat trzech kroków (widzieć - ocenić - działać) został zastosowany również podczas obrad Soboru Watykańskiego II, a szczególnie w czasie prac nad kształtem Konstytucji duszpasterskiej o Kościele w świecie współczesnym Gaudium et spes. Punktem wyjścia w tej konstytucji jest opis i analiza problemów współczesnego świata, następnie od pytań egzystencjalnych przechodzi się do teologicznej refleksji nad nimi i próby wskazania kierunków działania Kościoła $^{34}$.

Według paradygmatu J. Cardijna trzeba najpierw rozpoznać poprawnie zjawisko, które się analizuje, następnie dokonać oceny tego zjawiska w świetle kryteriów teologicznych, aby w końcu wyprowadzić z konfrontacji opisu zjawiska i jego oceny wnioski dla aktualnej działalności zbawczej Kościoła ${ }^{35}$. Element kairologiczny występujący w paradygmacie Cardijna zobowiązuje do sięgnięcia po wyniki badań empirycznych, które pozwalają w miarę możliwości obiektywnie rozpoznać zjawisko ${ }^{36}$. Ten proces został określony przez Sobór Watykański II jako odczytywanie znaków czasu (zob. KDK 4) ${ }^{37}$. Następnie następuje refleksja nad rozpoznanym zjawiskiem, a właściwie jego teologiczna interpretacja. Dopiero po etapie kryteriologicznym następuje konstruowanie konkretnych wniosków, postulatów i norm, które dotyczą działania Kościoła.

Synod diecezjalny zorganizowany według paradygmatu J. Cardina zaczyna się od badań empirycznych, które pozwalają lepiej rozeznać sytuację religijną i społeczną $\mathrm{w}$ diecezji ${ }^{38}$. W ten schemat wpisują się również synody, które poszukiwały tematyki obrad wśród wiernych. W tym celu posługiwano się ankietą skierowaną reprezentacyjnie do wiernych diecezji: duchownych, przedstawicieli

\footnotetext{
${ }^{33}$ Niemiecki pastoralista J. M ü 11 e r opisuje paradygmat trzech kroków słowami: diagnoza refleksja - akcja [zob. J. M ü 11 e r: Pastoraltheologie. Ein Handbuch für Studium und Seelsorge. Graz - Wien - Köln 1993 s. 94].

${ }^{34}$ W. P r z y g o d a, dz. cyt., s. 35.

${ }^{35}$ B. M i e r z wiń s ki: Teologia pastoralna czy teologia praktyczna. Spór o nazwę czy o koncepcję? „Ateneum Kapłańskie”. T. 144: 2005 nr 576 s. 230-231; zob. J. H o c h s t a f f 1: Die Konzeption von Praxis. W: Handbuch Praktische Theologie. Hg. H. H a s 1 i n g e r. Bd 1. Grundlegungen. Mainz 1999 s. 324-332.

${ }^{36}$ W. P r z y g o d a, dz. cyt., s. 34.

${ }^{37}$ Sobór docenił znaczenie nauk społecznych: $W$ duszpasterstwie należy uznać $i$ stosować $w$ dostatecznej mierze nie tylko zasady teologiczne, lecz także zdobycze nauk świeckich, zwtaszcza psychologii $i$ socjologii, tak aby prowadzić wiernych do czystszego i dojrzalszego życia wiary (KDK 62).

${ }^{38}$ Taki schemat przyjęła diecezja płocka - zob. Postawy religijno-społeczne mieszkańców diecezji płockiej. Raport z badań przeprowadzonych przez. Instytut Statystyki Kościoła Katolickiego $S A C$. Red. L. A d a m c z y k, W. Z d a n i e w i c z. Płock 2010.
} 
życia konsekrowanego i świeckich. Celem takich badań było zdobycie materiału do układania schematów i podjęcia decyzji synodalnych ${ }^{39}$.

W organizacji synodu można również zastosować pewne elementy paradygmatu analizy teologii pastoralnej, w którym punktem wyjścia jest etap kryteriologiczny, potem następuje etap kariologiczno-socjologiczny, a punktem dojścia jest etap prakseologiczny ${ }^{40}$. Jednak w takim schemacie postępowania synodalnego najczęściej etap kariologiczno-socjologiczny jest mniej rozbudowany, czasem nawet lekceważony. Jego słabością jest brak odwołania do wyników badań socjologicznych. Rozpoznanie sytuacji ogranicza się do dyskusji nad proponowanymi schematami w poszczególnych zespołach synodalnych. Jest to pewien rodzaj weryfikacji tego jak być powinno (normy) $\mathrm{z}$ tym jak jest (głos członków zespołów np. parafialnych). Taki schemat znajduje zastosowanie w synodach diecezjalnych, które wpisują się w formułę kanoniczną.

\section{Dialog jako podstawowa metoda pracy synodalnej}

Idea kolegialności, w którą wpisuje się synod diecezjalny, dowartościowana w teorii pastoralnej, w praktyce może pozostać martwa, jeśli nie zostanie wsparta przez dialog. Kościół nie ma struktury demokratycznej, ale hierarchiczną. Jednak eklezjologia wypracowana na Soborze Watykańskim II a rozwijana w nauczaniu posoborowym daje wyraźne podstawy do stworzenia płaszczyzny dialogu i współodpowiedzialności wszystkich członków Ludu Bożego w budowaniu wspólnoty eklezjalnej, także w wymiarze diecezjalnym. Nie należy dzisiaj przeprowadzać ostrej linii demarkacyjnej pomiędzy ustrojem demokratycznym a strukturą Kościoła ${ }^{41}$.

Demokrację w Kościele zastępuje idea kolegialności i zasada dialogu ${ }^{42}$. W praktyce udaje się to zrealizować przez budowanie braterskiej wspólnoty oraz sprawowanie władzy w duchu służby i miłości. Dążąc do współodpowiedzialności i współuczestnictwa wszystkich członków Ludu Bożego, również katolików świeckich, w misji Chrystusa, biskupi powinni promować instytucję synodów

${ }^{39}$ Por. W. W ó j c i k: Synod diecezjalny w Nowym Kodeksie Prawa Kanonicznego, dz. cyt., s. $116-117$.

${ }^{40}$ R. K a m i ń s k i: Wprowadzenie do teologii pastoralnej. Kraków 2001 s. 118-120.

${ }^{41}$ Kościół-Wspólnota $w$ pewnym sensie jest demokracja. Nie stanowi przecież zrzeszenia pasterzy dla obstugi stuchajacych i nawróconych świeckich, ale jeden lud, który wstuchuje się w to samo stowo Boże. Podstawa przynależności do niego oraz wszystkich postannictw i godności $w$ nim jest ten sam chrzest. Duch Święty daruje się wszystkim uczniom Chrystusowym - każdy może cieszyć się zmystem wiary $i$ każdemu może być dany charyzmat dla zbudowania wspólnot $[\mathrm{H}$. $\mathrm{S}$ e w e r y n i a k: Święty Kościót powszedni, dz. cyt., s. 72].

${ }^{42}$ Zob. J. W a l: Rola dialogu w życiu Kościoła. W: Teologia pastoralna. Red. R. K a m i ń s k i. T. 1. Teologia pastoralna fundamentalna. Lublin 2000 s. 188-203. 
diecezjalnych. Na hierarchii kościelnej, z racji jest szczególnej roli w budowaniu Kościoła, spoczywa obowiązek wykorzystywania sprawdzonych mechanizmów demokratycznych ${ }^{43}$. Należy podkreślić, że prawo wyznacza pewne ramy działania, natomiast nie reguluje całego życia Kościoła. Stwarza podstawy do dalszego rozwoju zasady współodpowiedzialności. Na synodach zawsze poszukiwano zgody zarówno w zwyczajnych relacjach wspólnotowych, jak też konkretnych rozwiązań pastoralnych ${ }^{44}$.

Trzeba jednak zaznaczyć, że głosowań na synodach nie można porównywać do znanych współcześnie głosowań demokratycznych, w których arytmetyczna większość decyduje o ważności decyzji. Głosowania synodalne mają na celu jedynie zweryfikowanie wspólnej tradycji. Takie działanie jest porównywalne do badania świadectw przed trybunałem, albowiem zgodność tych świadectw zapewnia prawdziwość danego stwierdzenia lub wydarzenia. Zgodność Kościołów i ich pasterzy stanowi kryterium autentycznej tradycji, ale nie podstawę jej ważności ${ }^{45}$. Warto pamiętać, że już starożytne prawo kościele przejęło następujący aksjomat ze świeckiego prawa rzymskiego: Quod omnes tangit, ab omnibus tractari et approbari debet ${ }^{46}$.

Dowartościowanie dialogu, a tym samym powrót po praktyki pierwotnego Kościoła, przyniosła nauka Soboru Watykańskiego II. Soborowa wizja Kościoła-Wspólnoty, w którym wola autentycznego braterstwa winna cechować wszelkie relacje z ludźmi, odpowiada dialogicznej formie komunikacji ${ }^{47}$. Pojęcie ,dialogu", stosowane czasem zamiennie z colloquium, stało się dla Soboru kluczowym. Papież Paweł VI w swojej pierwszej encyklice Ecclesiam suam (06.08.1964) uczynił z tego pojęcia program działania dla Kościoła. Papież zachęcał nie tylko do dialogu $\mathrm{z}$ wyznawcami innych religii i niewierzącymi, ale postulował dialog wewnątrzkościelny.

Dialog (od gr. dialegein - rozmawiać, dyskutować, dociekać) należy rozumieć jako proces wzajemnej wymiany myśli, dawania świadectwa i komunikacji mitości, zachodzacy $w$ trakcie interpersonalnego spotkania ludzi prawego umystu, dobrej woli i szczerych uczuć, którzy poprzez społeczne odkrywanie prawdy, obronę wartości ogólnoludzkich oraz poszukiwanie możliwości wspótpracy w realizacji dobra wspólnego, zmierzaja do integralnego rozwoju osobowości,

${ }^{43}$ Tamże.

${ }^{44}$ H. H. P o $t$ t m e y e r: Dialog jako wzorzec komunikacji eklezjalnej. W: Osoba we wspólnocie. Kościót Chrystusowy. Kolekcja „Communio”. T. 16. Red. L. B a 1 t e r, S. D u s z a, A. P i ę t k a. Poznań. Pallotinnum 2004 s. 276.

${ }^{45}$ Tamże, s. 276-277.

${ }^{46}$ Wszyscy winni omawiać i aprobować to, co dotyczy wszystkich.

${ }^{47}$ H. H. P o t t m e y e r, dz. cyt., s. 273. 
budowania wspólnoty oraz odnowy i doskonalenia rzeczywistości $i^{48}$. Zakłada on uznanie godności i wolności każdego człowieka i jego prawo do wyrażania własnych poglądów. W soborowej Konstytucji duszpasterskiej o Kościele w świecie współczesnym Gaudium et spes znalazło się stwierdzenie, że Kościół ma być znakiem tego braterstwa, które umożliwia $i$ umacnia szczery dialog. Wymaga to jednak postawy wzajemnego szacunku poszukiwania zgody, uznajac wszelkie uprawnione zróżnicowanie w celu utrwalania coraz owocniejszego dialogu między wszystkimi, którzy tworzq Lud Boży. Silniejsze jest bowiem to, co wiernych taczy, niż to, co ich dzieli: niechaj w sprawach koniecznych panuje jedność, w watpliwych - wolność, we wszystkich zaś mitość (KDK 92). Z nauczania kościelnego wynika, że dialog jest takim komunikowaniem się międzyosobowym, w którym partnerzy szanuję się nawzajem w swojej wolności i niepowtarzalności. Poza tym czują się zobowiązani do mówienia prawdy oraz traktują poważnie wiedzę i doświadczenie partnera dialogu ${ }^{49}$.

Jest wiele przeszkód na drodze dialogu, jednak nie powinny one zniechęcać do stosowania tej metody ${ }^{50}$. Skoro wszyscy wierni uczestniczą we właściwy sobie sposób w budowaniu Kościoła istnieje potrzeba nieustannego dialogu hierarchii kościelnej z przedstawicielami życia konsekrowanego i wiernymi świeckimi (por. KK 37, DA 24) ${ }^{51}$. Niewątpliwie okazją do tak pojętego dialogu jest synod diecezjalny ${ }^{52}$.

${ }^{48}$ J. W a l: Dialog. W: Leksykon teologii pastoralnej. Red. R. K a m i ń s k i, W. P r z y g o d a, M. F i a ł k o w s k i. Lublin 2006 s. 175.

${ }^{49}$ H. H. P o t t m e y e r, dz. cyt., s. 274.

${ }^{50}$ Papież P a w e $\nmid$ V I wskazał na irenizm i synkretyzm, jako na zagrożenia dialogu (ES 88). Irenizm w imię źle pojętej tolerancji dla rozmówcy nie podejmuje trudnych tematów, lecz tylko sprawy drugorzędne i zastępcze. W synkretycznym dialogu poprzestaje się na powierzchownej zgodności, nie docierając do meritum problemu. Osiagana na tej drodze jedność jest pozorna. Przeszkodą w dialogu może być także neognostycyzm, który polega na absolutyzacji dialogu i naiwnym przekonaniu, że przy jego pomocy uda się rozwiązać wszystkie problemy. Wśród zagrożeń dialogu niektórzy autorzy wymieniają nadto instrumentalizm, który prowadzi do urzeczowienia partnera dialogu i posługiwania się nim dla realizacji własnych, często ukrytych celów. Podobnie postawa utylitarna, polega na szukaniu tylko własnej korzyści. Papież Jan Paweł II wskazuje na niebezpieczeństwo spektakularyzmu w dialogu. Dialog prowadzony w świetle reflektorów i kamer często traci swój pozytywny walor, bo na pierwszy plan wysuwa się dbałość o wizerunek i chęć zwycięstwa, a nie służba prawdzie - zob. Z. K a t a: Dialog wewnatrzkościelny w nauczaniu Jana Pawta II. Zarys problematyki. „Studia Sandomierskie”. T. 9: 2002 s. 135-159.

${ }^{51}$ A. L. S z a f r a ń s k i: Kariologia. Zarys nauki w Kościele w świecie wspótczesnym. Lublin 1990 s. 256.

${ }^{52}$ Po Soborze Watykańskim II powołano do życia różne struktury, które mają ułatwić prowadzenie dialogu. Jednak trzeba pamiętać, że kolegialność iure divino odnosi się jedynie do biskupów zebranych z papieżem na Soborze Powszechnym. Wszystkie inne formy kolegialności są zastosowaniem tej zasady w życiu Kościoła i oparte są na prawie kościelnym. 